\title{
ANALISIS MISKONSEPSI SISWA KELAS V-B MIN BUDURAN SIDOARJO PADA MATERI PECAHAN DITINJAU DARI KEMAMPUAN MATEMATIKA
}

\author{
Ziadatul Malikha ${ }^{1}$, Mohammad Faizal Amir ${ }^{2}$ \\ Pendidikan Guru Sekolah Dasar, Universitas Muhammadiyah Sidoarjo, Indonesia \\ Choizea06@gmail.com
}

\begin{abstract}
Abstrak: Miskonsepsi yang terjadi pada siswa akan mengakibatkan siswa mengalami kesalahan juga untuk konsep pada tingkat berikutnya. Sehingga mengakibatkan terjadinya rantai kesalahan konsep yang tidak terputus karena konsep awal yang telat dimiliki akan dijadikan sebagai dasar belajar konsep selanjutnya. Pecahan merupakan cabang dari aritmatika yang sangat erat kaitannya dengan kehidupan sehari-hari dan merupakan materi yang berhubungan dengan materi yang lain. Namun mesikipun demikian masih banyak siswa yang mengalami miskonsepsi dalam memahami konsep pecahan. Tujuan penelitian ini adalah untuk mengetahui miskonsepsi yang terjadi pada siswa berkemampuan matematika tinggi, sedang dan rendah dan untuk mengetahui seberapa besar presentasi miskonsepsi yang dialami. Jenis penelitian yang digunakan adalah penelitian kualitatif. Teknik pengumpulan data yang digunakan adalah 1) Tes kemampuan matematika untuk mengetahui kemampuan matematika subjek, 2) tes diagnostik miskonsepsi untuk mengetahui miskonsepsi yang terjadi, dan 3) wawancara yang dilakukan pada subjek yang mengalami miskonsepsi terbanyak. Pengecekan keabsahan data menggunakan trianggulasi teknik, yaitu dengan membandingkan data hasil tes, wawancara dan dokumentasi. Hasil penelitian dapat dipaparkan sebagai beriku. 1) miskonsepsi pada siswa berkemampuan matematika tinggi sebesar 20\%, yaitu pada konsep makna, urutan dan kerapatan pecahan, 2) miskonsepsi pada siswa berkemampuan matematika sedang sebesar 60\%, yaitu pada konsep definisi, makna, ketaksamaan pecahan, urutan dan kerapatan pecahan serta perkalian dan pembagian pecahan, dan 3) miskonsepsi pada siswa berkemampuan matematika rendah sebesar 30\%, yaitu pada konsep makna, ketaksamaan, urutan atau kerapatan dan perkalian pecahan.
\end{abstract}

Kata Kunci: miskonsepsi; pecahan; kemampuan matematika.

\section{Pendahuluan}

Salah satu mata pelajaran yang diajarkan di sekolah yang sangat erat kaitannya dalam kehidupan sehari-hari adalah mata pelajaran matematika. Berdasarkan Permendiknas No. 22 Tahun 2006 pemberian mata pelajaran matematika disekolah dasar dimaksudkan untuk mengenal, menyikapi dan mengapresiasi ilmu pengetahuan dan teknologi, serta menanamkan kebiasaan berpikir dan berperilaku ilmiah yang kritis, kreatif dan mandiri.

Dari paparan pentingnya pembelajaran matematika di atas, terdapat fakta bahwa pada kenyataannya pembelajaran pada matematika ternyata menjadi pelajaran yang dihindari oleh sebagian siswa. Pelajaran matematika dianggap sebagai mata pelajaran yang sulit, serius, dan hanya berisi kumpulan rumus. Sebagaimana pendapat Turmudi (dalam Wahidin), matematika merupakan pelajaran yang menakutkan bagi sebagian siswa, dan menggejala baik di tingkat SD, SMP, maupun SMA. Mengingat pentingnya pembelajaran matematika untuk kehidupan serta matematika di sekolah dasar mengajarkan konsep dasar yang dijadikan landasan untuk belajar pada 
jenjang berikutnya, maka perlu adanya identifikasi lebih mengenai faktor-faktor penyebab matematika menjadi pelajaran yang menakutkan di tingkat sekolah dasar.

Berdasarkan observasi yang dilakukan peneliti pada tanggal 16 April 2016 diperoleh data hasil belajar siswa V-B pada mata pelajaran matematika dikatagorikan rendah jika dibandingkan dengan hasil belajar siswa di kelas V MIN Buduran Sidoarjo. Data hasil belajar siswa dapat dilihat pada Tabel 1 berikut:

Tabel 1. Data Hasil Belajar Siswa Kelas V MIN Buduran Sidoarjo Semester II Tahun Ajaran 2015-2016

\begin{tabular}{cccc}
\hline Kelas & UTS & UAS & Rata-rata \\
\hline V-A & 82,4 & 82,8 & 82,6 \\
\hline V-B & 80,3 & 80,7 & 80,5 \\
\hline
\end{tabular}

Dapat dilihat dari Tabel 1. ratarata nilai UTS dan UAS kelas V-B lebih rendah dibandingkan dengan kelas V-A. Dengan adanya hasil belajar matematika yang rendah, dapat diketahui bahwa siswa belum memahami konsep-konsep matematika dengan benar atau siswa mengalami miskonsepsi.

Miskonsepsi yang terjadi pada siswa akan mengakibatkan siswa mengalami kesalahan juga untuk konsep pada tingkat berikutnya. Sehingga mengakibatkan terjadinya rantai kesalahan konsep yang tidak terputus karena konsep awal yang telat dimiliki akan dijadikan sebagai dasar belajar konsep selanjutnya. Kadarisman (2013) dan Amir (2015).

Pecahan merupakan cabang dari aritmatika yang sangat erat kaitannya dengan kehidupan sehari-hari dan merupakan materi yang berhubungan dengan materi yang lain. Namun meskipun demikian berdasarkan dari beberapa penelitian pada bidang matematika, masih banyak siswa yang mengalami miskonsepsi dalam memahami konsep pecahan.

Berdasarkan penjelasanpenjelasan di atas miskonsepsi yang terjadi pada siswa dalam menyelesaikan materi pecahan perlu diperhatikan dan dilakukan penelitian berupa analisis miskonsepsi. Analisis miskonsepsi adalah suatu upaya yang dilakukan untuk memahami dan menjelaskan miskonsepsi dengan memilah dan menguraikan dalam bentuk deskripsi untuk mendapatkan kebenaran akan miskonsepsi yang terjadi. Analisis miskonsepsi yang dilakukan dalam penelitian ini dengan mengungkap secara mendalam miskonsepsi yang terjadi pada siswa berkemampuan matematika tinggi, rendah dan sedang.

1. Konsep, Konsepsi, dan Miskonsepsi

Menurut Gagne (Karso, 2011), konsep adalah ide abstrak yang memungkinkan kita mengelompokkan benda-benda ke dalam contoh dan bukan contoh, seperti suatu segitiga dengan yang bukan suatu segitiga, antara bilangan asli dengan yang bukan bilangan asli, dan seterusnya.

Pemikiran dan pemahaman setiap orang pada suatu konsep bisa saja berbedabeda. Meskipun dalam matematika kebanyakan konsep telah mempunyai arti yang jelas yang telah disepakati oleh para ilmuan matematika, konsepsi siswa masih bisa berbeda-beda, hal ini bisa dikarenakan karena andanya konsep-konsep yang telah dimiliki sebelumnya. Berg (dalam yuanita, 2014) mengatakan konsepsi adalah pengertian atau tafsiran seseorang terhadap suatu konsep tertentu dalam kerangka yang sudah ada dalam pikirannya dan setiap konsep baru didapatkan dan diproses dengan konsep-konsep yang telah dimiliki.

Pemahaman siswa sebelum mereka mempelajari konsep secara formal di sekolah disebut konsepsi awal 
(prakonsepsi).

Ibrahim

(2012) menyatakan suatu prakonsepsi biasanya lebih mudah berubah. Prakonsepsi akan berubah manakala siswa yang bersangkutan diajari konsep yang sebenarnya. Bila suatu prakonsepsi tidak mudah berubah, dan orang yang memiliki prakonsepsi tersebut selalu kembali kepada prakonsepsinya sendiri meskipun telah diperkenalkan dengan konsep yang benar, hal itu dinamakan miskonsepsi. Hal ini sesuai pendapat Bodner (dalam Suwarto, 2013) bahwasannya miskonsepsi sangat sulit diubah, karena setiap orang membangun pengetahuannya persis dengan pengalamannya.

Suparno (dalam Suwarto, 2013) mendifinisikan miskonsepsi lebih menditail, yaitu miskonsepsi sebagai pengertian yang tidak akurat akan konsep, penggunaan konsep yang salah, klasifikasi contoh-contoh yang salah, kekacauan konsep-konsep yang berbeda, dan hubungan hirarkis konsep-konsep yang tidak benar.

Dari beberapa definisi miskonsepsi di atas dapat disimpulkan bahwa miskonsepsi adalah pemahaman yang tidak akurat akan konsep, penggunaan konsep yang tidak sesuai dengan konsep yang telah disepakati secara ilmiah oleh pakar ahli dalam bidang tersebut, ketidak mampuan dalam menghubungkan konsep awal dengan konsep selanjutnya secara benar dan bersifat resisten atau sulit diubah.

Menurut Budiharjo (dalam Pegu, 2014) siswa diakatakan memahami konsep apabila:

a. Menyatakan ulang sebuah konsep.

b. Mengklasifikasi obyek-obyek menurut sifat-sifat tertentu (sesuai dengan konsepnya).

c. Memberikan contoh dan non contoh dari konsep.

d. Menyajikan konsep dalam bentuk representatif atau simbol matematis. e. Mengembangkan syarat perlu atau syarat cukup suatu konsep.

f. Menggunakan, memanfaatkan dan memilih prosedur atau operasi tertentu.

g. Mengembangkan konsep atau algoritma dalam pemecahan masalah

Dari indikator pemahaman konsep di atas dapat dikatakan siswa mengalami miskonsepsi apabila :

a. Terjadi pemahaman suatu konsep yang tidak akurat yang tidak sesuai dengan konsep yang telah diterima dan disepakati secara ilmiah oleh pakar ahli dalam bidang tersebut.

b. Menyatakan ulang konsep secara tidak benar.

c. Tidak benar dalam mengklasifikasikan obyek-obyek dari konsep.

d. Tidak benar dalam membedakan mana yang merupakan contoh konsep dan yang bukan contoh konsep.

e. Tidak benar dalam menyajikan konsep dalam bentuk lain yang lebih sederhana atau dalam bentuk simbol-simbol matematika.

f. Tidak mengetahui secara benar syarat perlu dan syarat cukup dari suatu konsep.

g. Menggunakan konsep yang salah dalam menerapkan konsep dengan prosedur atau operasi tertentu.

h. Tidak dapat mengembangkan konsep dengan benar, dan tidak menggunakan konsep sebenarnya namun menggunakan konsep yang lain yang berbeda dengan konsep yang telah diterima dan disepakati secara ilmiah oleh para ahli dalam memecahkan masalah.

2. Kemampuan Matematika

Setiap orang memiliki kemampuan berbeda-beda dalam belajar matematika. Ada sebagian orang yang mampu belajar lebih cepat 
dibandingkan dengan yang lain. Kemampuan matematika sangat berpengaruh baik dalam hal memahami dan menyelesaikan masalah matematika. Kemampuan matematika pada penelitian ini adalah kemampuan intelektual siswa yang dilihat dari hasil tes kemampuan matematika.

Dalam penelitian ini siswa dikategorikan menjadi tiga kategori berdasarkan kemampuan matematikannya, yaitu kemampuan tinggi, kemampuan sedang, dan kemampuan rendah.

Tabel 2. Kriteria Kemampuan matematika

\begin{tabular}{lll}
\hline No & \multicolumn{1}{c}{ Skor } & \multicolumn{1}{c}{ Kategori } \\
\hline 1. & $80 \leq \mathrm{x} \leq 100$ & Kemampuan Tinggi \\
\hline 2. & $60 \leq \mathrm{x}<80$ & Kemampuan Sedang \\
\hline 3. & $0 \leq \mathrm{x}<60$ & Kemampuan Rendah \\
\hline
\end{tabular}

\section{Tes Diagnostik Miskonsepsi}

Suwarto (2013) menyatakan tes diagnostik adalah tes yang digunakan untuk mengetahui kelemahan atau miskonsepsi pada topik tertentu dan mendapatkan masukan tentang respons siswa untuk memperbaiki kelemahannya.

Tes diagnostik dapat berupa tes pilihan ganda atau tes benar salah dengan pembetulan (Ibrahim, 2012). Dalam penelitian ini menggunakan tes benar salah dengan pembetulan dan alasan terbuka karena dengan tes pernyataan benar salah tampak letak kesalahan konsep siswa (miskonsepsi) yang menyebabkan jawaban siswa tidak benar.

\section{Metode Penelitian}

Penelitian ini merupakan penelitian deskriptif kualitatif untuk mendeskrrpsikan secara mendalam miskonsepsi yang terjadi pada siswa kemampuan matematika tinggi, sedang, dan rendah pada materi pecahan. Subjek penelitian adalah siswa MIN Buduran Sidoarjo tahun ajaran 2015-2016 kelas VB yang terdiri dari 36 siswa. Ruang lingkup pembahasan materi pecahan dalam penelitian ini menyesuaikan Standar Kompetensi (SK) dan Kompetensi Dasar (KD) kurikulum KTSP 2006 SD/MI Kelas V salah satu SK yang memuat materi pecahan. Dalam penelitian ini peneliti memfokuskan pada definisi pecahan dan KD 5.3 Mengalikan dan membagi berbagai bentuk pecahan.

Untuk mendapatkan data penelitian, teknik pengumpulan data yang dilakukan sebagai berikut: (1) Tes kemampuan matematika siswa, butir-butir soal tes dipilih dari soal UAS semester ganjil tahun 2015 yang telah diubah menjadi soal uraian dan terdiri dari 4 butir soal. Tes digunakan untuk mengelompokkan subjek berdasarkan kemampuan matematika tinggi, sedang, dan rendah. (2) tes diagnostik miskonsepsi yang terdiri dari 10 butir pernyataan benar salah disertai dengan alasan terbuka, tes ini dugunakan untuk mendiagnositik miskonsepsi yang terjadi pada siswa, tes ini divalidasi oleh dua validator ahli yakni dosen PGSD dan kepala sekolah konsentrasi matematika. (3) wawancara kepada subjek dengan menggunakan pedoman wawancara untuk menggali informasi lebih mendalam dari hasil pengerjaan tes tulis subjek. Hasil tes 36 subjek dikelompokkan berdasarkan kemampuan matematika tinggi, sedang, dan rendah, selanjutnya dipilih 2 subjek yang masing-masing mewakili miskonsepsi yang terjadi pada setiap kemampuan matematika tinggi, rendah, dan sedang untuk diwawancarai.

Analisis data penelitian ini menggunakan tahap-tahap reduksi data, penyajian data, dan simpulan. Proses analisis tersebut sebagai berikut:

1. Reduksi Data

Pada tahap ini, kegiatan yang dilakukan meliputi kegiatan dalam memilih, menyederhanakan, menggolongkan, dan menajamkan data 
yang diperoleh dari hasil tes dan wawancara subjek agar diperoleh data yang sesuai kebutuhan. Data berupa hasil tes akan ditabulasi berdasarkan kategori jawaban tidak paham konsep, miskosnepsi, dan paham konsep. Pada jawaban yang miskonsepsi akan dianalisis sesuai dengan indikator miskonsepsi pada pecahan untuk menjawab pertanyaan peneliti.

2. Penyajian Data

Peneliti menyajikan data yang diperoleh dari tahap reduksi data. Data yang akan disajikan berupa data tes diagnostik miskonsepsi pecahan, dan data wawancara. Penyajian data dalam penelitian ini menggunakan teks naratif.

3. Kesimpulan

$$
\text { Penarikan kesimpulan yang }
$$
didasarkan pada data yang telah disajikan dengan tujuan untuk memperoleh kesimpulan tentang miskonsepsi yang terjadi pada siswa berkemampuan matematika tinggi, sedang, dan rendah pada bahasan pokok materi pecahan.

Untuk memeriksa keabsahan data penelitian, peneliti menggunakan triangulasi teknik dengan cara memeriksa data kepada subjek yang sama dengan teknik berbeda yakni tes, wawancara, dan dokumentasi (Sugiyono, 2015).

\section{Hasil dan Pembahasan}

Berikut merupakan hasil jawaban 36 subjek yang berdasarkan kategori jawaban tidak paham, miskonsepsi dan paham konsep yang telah dikelompokkan berdasarkan kemampuan matematika.

\begin{tabular}{|c|c|c|c|c|c|c|c|c|c|}
\hline \multirow{2}{*}{$\begin{array}{c}\text { No. } \\
\text { soal }\end{array}$} & \multicolumn{10}{|c|}{ Presentase } \\
\cline { 2 - 11 } & \multicolumn{2}{|c|}{ Kemp. Tinggi } & \multicolumn{3}{c|}{ Kemp. Sedang } & \multicolumn{3}{c|}{ Kemp. Rendah } \\
\cline { 2 - 11 } & $\mathrm{TP}$ & $\mathrm{M}$ & $\mathrm{P}$ & $\mathrm{TP}$ & $\mathrm{M}$ & $\mathrm{P}$ & $\mathrm{TP}$ & $\mathrm{M}$ & $\mathrm{P}$ \\
\hline 1 & 22,2 & 33,3 & $\mathbf{4 4 , 4}$ & 5,8 & $\mathbf{5 8 , 8}$ & 35,2 & $\mathbf{5 0}$ & 30 & 20 \\
\hline 2 & 0 & $\mathbf{8 8 , 8}$ & 11,1 & 5,8 & $\mathbf{9 4 , 1}$ & 0 & 20 & $\mathbf{8 0}$ & 0 \\
\hline 3 & 0 & 11,1 & $\mathbf{8 8 , 8}$ & 0 & 17,6 & $\mathbf{8 2 , 3}$ & $\mathbf{5 0}$ & 30 & 20 \\
\hline 4 & 22,2 & 33,3 & $\mathbf{4 4 , 4}$ & 0 & $\mathbf{6 4 , 7}$ & 35,2 & $\mathbf{5 0}$ & 20 & 30 \\
\hline 5 & 11,1 & 0 & $\mathbf{8 8 , 8}$ & 29,4 & 5,8 & $\mathbf{6 4 , 7}$ & 40 & 0 & $\mathbf{6 0}$ \\
\hline 6 & 44,4 & $\mathbf{5 5 , 5}$ & 0 & 47 & $\mathbf{5 2 , 9}$ & 0 & 30 & $\mathbf{6 0}$ & 10 \\
\hline 7 & 0 & $\mathbf{7 7 , 7}$ & 22,2 & 5,8 & $\mathbf{7 0 , 5}$ & 23,5 & 10 & $\mathbf{6 0}$ & 30 \\
\hline 8 & 0 & 33,3 & $\mathbf{6 6 , 6}$ & 0 & $\mathbf{7 6 , 4}$ & 23,5 & 10 & 40 & $\mathbf{5 0}$ \\
\hline 9 & 22,2 & $\mathbf{4 4 , 4}$ & 33,3 & 11,7 & 29,4 & $\mathbf{5 8 , 8}$ & 30 & $\mathbf{6 0}$ & 10 \\
\hline 10 & 0 & 33,3 & $\mathbf{6 6 , 6}$ & 23,5 & $\mathbf{4 1 , 1}$ & 35,3 & 30 & 10 & $\mathbf{6 0}$ \\
\hline
\end{tabular}

Gambar 1. Tabel Presentase Jawaban Subjek Menyelesaikan Tes Diagnostik Berdasarkan Kemampuan Matematika

Dari Gambar.1 diketahui bahwa banyaknya siswa kemampuan matematika tinggi mengalami miskonsepsi pada pernyataan nomor 2 , 6, 7, dan 9 sebesar $88,8 \%, 55,5 \%$, $77,7 \%$, dan 44,4 persen. Sedangkan banyaknya siswa kemampuan matematika sedang mengalami miskonsepsi pada nomor $1,2,4,6,7,8$, dan 10 dengan presentase sebesar 58,8\%, 94,1\%, $64,7 \%, 52,9 \%, 70,5 \%, 76,4 \%$, dan $41,1 \%$ dan banyaknya siswa kemampuan matematika rendah mengalami miskonsepsi pada nomor 2, 6, 7, dan 9 sebesar $80 \%, 60 \%, 60 \%, 60 \%$. Setelah dilakukan analisis data dan pengecekan keabsahan data menggunakan trianggulasi teknik, diperoleh data yang valid mengenai miskonsepsi yang terjadi pada siswa kemampuan matematika tinggi, sedang, dan rendah sebagai berikut:

1. Miskonsepsi Siswa

Kemampuan Matematika Tinggi (KMT)

Siswa dengan kemampuan matematika tinggi mengalami miskonsepsi paling sedikit dibandingkan dengan siswa lainnya. Miskonsepsi yang terjadi adalah:

a. Makna pecahan yang merupakan bagian dari keseluruhan diartikan berbeda oleh siswa, yakni siswa tidak memperhatikan bagianbagian dari keseluruhan tersebut besarnya adil atau tidak. Konsep tersebut merupakan syarat perlu dalam menentukan nilai pecahan dari suatu gambar.

b. Pada konsep urutan dan kerapatan bilangan pecahan siswa menganggap konsep urutan pada bilangan pecahan sama dengan konsep urutan bilangan cacah jika penyebut pecahan sama. konsep sebenarnya pada sifat 
kerapatan bilangan pecahan adalah diantara dua bilangan pecahan tak senilai terdapat pecahan lain yang jumlahnya tidak terbatas (Purnomo 2015).

2. Miskonsepsi Siswa Kemampuan Matematika Sedang (KMS)

Siswa dengan kemampuan matematika sedang mengalami miskonsepsi terbanyak dibandingkan dengan subjek lainnya. Miskonsepsi yang terjadi adalah:

a. Menurut siswa bilangan pecahan adalah jika ada pembilang dan penyebut serta ada garis pernya, pembilang dan penyebut berupa sembarang bilangan, termasuk bilangan nol.

b. Menurut siswa bagian dari suatu pecahan tidak perlu sama dengan bagian yang lainnya. Konsep yang dipahami siswa tidak sesuai dengan konsep yang telah disepakati oleh pakar matematikawan, bahwasannya bilangan pecahan dapat ditunjukkan sebagai perbandingan bagian yang sama terhadap keseluruhan dari suatu benda atau himpunan bagian yang sama terhadap keseluruhan dari suatu himpunan (Karso, 2013).

c. Siswa menggunakan cara yang tidak sesuai dengan konsep secara ilmiah yang telah disepakati oleh pakar ahlidalam menguji ketaksamaan nilai pecahan, Konsep yang digunakan secara simbolis dapat dituliskan $\frac{a}{b}>\frac{c}{d}$ jika dan hanya jika Bagian cb>ad

d. Pada konsep urutan dan kerapatan bilangan pecahan siswa mencari urutan dan kerapatan dari dua bilangan pecahan tersebut dengan mengurutkan pembilangnya seperti mengurutkan bilangan cacah karena penyebutnya sudah sama. Sebagian besar siswa menganggap urutan dan kerapatan bilangan pecahan yang sama penyebutnya, sama dengan urutan pada bilangan cacah. Hal ini sesuai dengan penemuan beberapa peneliti seperti Purnomo et all, 2014, McIntosh, Bana \& Farrell, 1997) bahwa sebagian besar siswa di SD mengalami miskonsepsi pada urutan dan kerapatan bilangan pecahan.

e. Pada konsep perkalian dan pembagian pecahan siswa menganggap hasil lebih besar dan ketika dibagikan hasilnya akan lebih kecil. Miskonsepsi ini terjadi dikarenakan ketidakmampuan siswa membedakan atribut (ciri penentu) konsep.

3. Miskonsepsi Siswa Kemampuan Matematika Rendah (KMR)

Siswa berkemampuan matematika rendah tidak memahami konsep paling banyak dari pada subjek lainnya. Miskonsepsi yang terjadi yaitu :

a. Siswa tidak mengetahui secara benar materi prasyarat (makna pecahan sebagai part to whole). Karena siswa tidak memperdulikan bagian yang diarsir sama atau tidak dengan bagian yang lainnya.

b. Pada konsep urutan dan kerapatan pecahan siswa mengalami miskonsepsi bahwa kerapatan bilangan pecahan sama dengan urutan pada bilangan asli.

c. Konsep perkalian pecahan siswa mengalami miskonsepsi bahwa hasil dari perkalian pecahan akan menghasilkan nilai yang lebih dari salah satu bilangan pengalinya. Miskonsepsi ini terjadi karena siswa juga mengalami miskonsepsi pada operasi perkalian pecahan dengan menggunakan konsep penjumlahan, yaitu menyamakan dulu penyebutnya kemudian menjumlahkan pembilangnya. 


\section{Kesimpulan}

Berdasarkan hasil penelitian, maka dapat diperoleh kesimpulan terkait fakta bahwa siswa kelas V-B MIN Buduran Sidoarjo sebagian besar mengalami miskonsepsi pada materi pecahan sebagai berikut:

1. Miskonsepsi dapat terjadi pada setiap siswa, baik siswa dengan kemampuan matematika rendah, sedang maupun tinggi. Presentase miskonsepsi terbesar terjadi pada siswa berkemampuan matematika sedang, sebesar 60\%. Sedangkan siswa berkemampuan rendah sebesar $30 \%$ dan siswa berkemampuan matematika tinggi mengalami miskonsepsi paling sedikit, yaitu sebesar $20 \%$.

2. Siswa kemampuan matematika tinggi mengalami miskonsepsi pada konsep makna pecahan dan urutan dan kerapatan pecahan.

3. Siswa kemampuan matematika sedang mengalami miskosnepsi pada konsep definisi pecahan, konsep makna pecahan, ketidaksamaan pecahan, urutan dan kerapatan pecahan, dan konsep perkalian dan pembagian pecahan.

4. Siswa kemampuan matematika rendah mengalami miskonsepsi pada konsep konsep makna pecahan, urutan dan kerapatan pecahan, perkalian pecahan.

\section{Daftar Rujukan}

Abdurrahman, M. 2012. Anak Berkesulitan Belajar. Jakarta: Rineka Cipta.

Ambarwati, D.R. 2011. Miskonsepsi Pada Materi Kelistrikan, Kemagnetan, dan Tata Surya Siswa SMP. Skripsi Universitas Negeri Semarang.

Amir, M. F. 2015. Analisis Kesalahan Mahasiswa PGSD Universitas Muhammadiyah Sidoarjo Dalam Menyelesaikan Soal
Pertidaksamaan Linier. Jurnal Edukasi, 1(2): 131-146.

Arikunto, S. 2006. Dasar-dasar Evaluasi Pendidikan. Jakarta: Bumi Aksara.

Direktorat Jendral Pendidikan Dasar dan Menengah. 2003. Pedoman Pengembangan Tes Diagnostik Bahasa Inggris SM. Jakarta: Ditjen Dikdasmen Depdiknas.

Ibrahim, M. 2012. Konsep, Miskonsepsi dan Cara Pembelajarannya. Surabaya: Unesa University Press

Dr. Suwarto. 2013. Pengembangan tes Diagnostik dalam Pembelajaran. Yogyakarta: Pustaka Pelajar.

Kadarisman. 2013. Miskonsepsi Siswa Dalam Penguasaan Materi Grafik Fungsi Kuadrat pada Kelas X SMAN I Sumenep. Tesis Universitas Negeri Surabaya.

Karso dkk. 2011. Pendidikan Matematika I. Jakarta: Universita Terbuka.

M, Dalyono. 2005. Prestasi Belajar. Jakarta: Renika Cipta.

Moleong. 2002. Metodologi Penelitian Kuantitatif. Bandung: PT Remaja Rosdakarya.

Pegu, Martianus. 2014. Miskonsepsi Siswa SMP Dalam Menyelesaikan Masalah Perbandingan. Tesis Universitas Negeri Surabaya.

Prasetyorini, Nanda. 2013. Profil Miskonsepsi Siswa Pada Materi Pokok Pecahan Ditinjau dari Kermampuan Matematika Siswa. ejournal UNESA. 2(1).

Purnomo, W. Y. 2015. Pembelajaran Matematika untuk PGSD. Jakarta: Erlangga.

Tayubi, Yuyu Rahmat. 2005. Identifikasi Miskonsepsi Pada Konsep-Konsep Fisika Menggunakan Certainty of Response Index (CRI). Jurnal Mimbar Pendidikan, 216(3).

Wahidin. 2013. Pola dan Kekeliruan Matematika, Tinjauan Terhadap Kemampuan Penalaran. Prosiding, Vol 1. 